\title{
PSYCHOTHERAPY TREATMENT OF NEGATIVE EMOTIONAL EXPERIENCES OF ADULTS WITH THE TECHNIQUE "INTERIORIZATION AND EXTERIORIZATION OF THE FOCUS OF ATTENTION"
}

\author{
Daria Bessonova \\ Postgraduate Student of the Department of General and Social Psychology and \\ Psychotherapy \\ National Pedagogical Dragomanov University \\ 9, Pyrohov Str., Kyiv, Ukraine, 01601 \\ bessonova.dariya@gmail.com, https://orcid.org/0000-0001-6722-7662 \\ Svitlana Stavytska \\ Doctor of Sciences in Psychology, Professor, \\ Head of the Department of General and Social Psychology and Psychotherapy \\ National Pedagogical Dragomanov University \\ 9, Pyrohov Str., Kyiv, Ukraine, 01601 \\ stavics@ukr.net, https://orcid.org/0000-0003-0800-0876
}

\begin{abstract}
The paper is devoted to the analysis of the peculiarities of the use of the psychotherapy technique of internalization and exteriorization of the focus of attention in the treatment of negative emotional experiences of adults. Negative emotional experiences are mental conditions of the individual that affect his self-esteem, assertiveness, and features of most mental processes. Negative emotional experiences, from which a person is not freed, can inhibit his personal development, form an inferiority complex, can be the cause of increased aggression or anxiety, can develop neurotic states. Psychotherapy treatment of negative emotional experiences is a difficult and unpleasant process for the client, which requires his conscious focus on overcoming such experiences, as well as high qualification and thorough professional skills of a psychotherapist. In this paper, as a psychotherapeutic intervention, a modified technique of "internalization and exteriorization of attention" is tested, which is based on the techniques of trauma-focused therapy, exposure-based techniques in cognitive behavioral therapy, and EMDR (Eye movement desensitization and reprocessing). The proposed technique of internalization and exteriorization of the focus of attention in psychotherapy treatment of negative emotional experiences is based on an alternating focus on negative experience (internalization of attention) and the actual external environment (exteriorization of attention) at equal intervals. Important here is the rhythm of processing emotional experiences and conscious control over their course. According to the results of the paper, the introduction of the technique of internalization and exteriorization of the focus of attention has improved the emotional state of the individuals: increased self-confidence, decreased fear of the future and anxiety, improved a positive trend of mood swings. The studied technique is quite narrowly focused on the processing of negative emotional experiences, but it was found that in the process of psychotherapy treatment also has a positive effect on the overall emotional state of the individuals.
\end{abstract}


Keywords: negative emotional experiences, psychotherapy treatment of negative emotional experiences, a technique of internalization and exteriorization of the focus of attention, cognitive behavioral therapy.

\section{Introduction}

People experience situations that are undesirable for them in different ways, depending on the peculiarities of their perception, stress resistance and inner readiness for life circumstances. Unpleasant memories that produce negative emotional experiences can accompany a person throughout life. Feelings of guilt, shame, resentment, frustration, longing, anxiety or fear affect the general emotional state of the person, his attitude to himself, his assertiveness and ability to enter and support close personal relationships and successful types (forms) of social interaction.

The scientific community pays considerable attention to the study of person's negative emotional experiences in terms of their identification (correlation) with other mental processes and states (Vekker, 1998), on the structure of experiences and their impact on various systems of the person (Izard, 2000).

Negative emotional experiences as a result of past psychological trauma have been studied for more than a century by foreign experts (Freud, 2012; Marcher \& Fich, 2007). In the context of psychotherapeutic interventions of negative emotional experiences related to past events, the works of such scientists are known - Antsupov \& Baklanovsky, 2006; Bondyreva, 2007; Briere \& Scott, 2015; Westbrook \& Kennerley, 2014; Leuner, 1996; Malkina-Pyh, 2005; Perls, 2004; Beck, 2005; Ellis \& Dryden, 1997; Shapiro, 2017 and others.

Domestic scientific research on the provision of psychological assistance to people with psychosomatic disorders (Kolesnichenko, 2019), the occurrence of which is associated with certain psychogenic factors (Ulko, 2020), with the experience of psychological trauma, features of emotional response to traumatic situations and events (Stavytska, Stavytsky \& Ulko, 2019).

Psychotherapy of negative emotional experiences is aimed primarily at reintegrating traumatic experiences and desensitizing negative emotions that bother the client. The purpose of psychotherapeutic interventions, in this case, is to assimilate the memories that cause negative emotional experiences at present moment. This allows the client to get rid of emotional suffering and actively, consciously and responsibly engage in the present life.

In the process of psychotherapy treatment with clients, the technique of internalization and exteriorization of the focus of attention was used to process negative emotional experiences. This technique is modified from the grounding technique in trauma-focused therapy, EMDR (Eye movement desensitization and reprocessing) and exposure-based techniques in cognitive behavioral therapy.

The proposed modified technique of internalization and exteriorization of the focus of attention in psychotherapy of person's negative emotional experiences is based on alternating focus of attention on negative emotional experience (internalization of attention) and the present external environment (exteriorization of attention).

To integrate any traumatic experience, it is necessary to re-experience the past situation with awareness of the negative experiences or emotions that accompanied it. The main thing here is the rhythm of re-experience, where immersion in negative experience is systematically and consistently replaced by awareness of the present moment, which allows a person to stop reproducing negative emotional experience and release from it. 
In the proposed technique, a client does not immerse himself in the negative experience completely (as in trauma-focused therapy and exposure-based techniques in cognitive-behavioral therapy) and does not keep focus of attention on negative experiences and stimuli of the present environment at the same time, as in EMDR. Person alternately focuses several times (individual rhythmic) on the negative emotional experience and the present external environment. In this case, there is an alternate concentration of attention with a focus on a particular object of the present environment or a negative experience from 3 to 15 seconds (individual interval). The technique of internalization and exteriorization of the focus of attention along with the diagnostic work used in 1 (one) therapeutic session separately for each study participant.

The purpose of the research is to carry out a theoretical substantiation and an empirical study of the effectiveness of the application of the technique of internalization and exteriorization of the focus of attention in the psychotherapy treatment of negative emotional experiences of adults. Objectives of the study: 1) to theoretically substantiate the essence of a person's negative emotional experiences; 2) to analyze the standardized techniques used in cognitive behavioral therapy in the treatment of negative emotional experiences of adults; 3) to present a modified technique of internalization and exteriorization of the focus of attention; 4) to highlight the empirical results of the study of the influence of the modified technique of internalization and exteriorization of the focus of attention in the psychotherapy treatment of negative emotional experiences.

\section{Research methods and techniques}

The empirical study involved 40 people aged 22 to 50 who sought psychological help for experiencing negative emotions and mental states caused by past critical traumatic events. The formative stage of the study was conducted for 20 people from the general sample who agreed to participate in psychotherapeutic treatment. For empirical research, we have selected methods aimed at diagnosing negative emotional experiences: the method of "A\&D" (anxiety and depression) (Karelin, 2007); method "Assessment Interview"; methods of mathematical statistics for quantitative processing of the obtained results.

Below we will focus on a brief description of each of the selected methods for determining the level and characteristics of experiencing negative mental states with which clients have applied.

Methodology “A\&D”. The application of this technique allowed to assess the general states of anxiety and depression in grades - positive mental states, satisfactory mental states, borderline mental states, negative (anxious or depressed) mental states.

At the stage of ascertaining research (immediately before introduction of psychotherapeutic treatment of technique of internalization and exteriorization of the focus of attention) and during psychotherapeutic session (formative stage of research) also assessment Interview was used which included specification of inquiry of the client concerning definition of the reasons, kinds and features of negative emotional experiences; concretization of the peculiarities of the experienced psychotraumatic experience and related negative emotional experiences in the structure of negative mental states. The identified emotions were evaluated by from 1 to 10 points $(1-$ a slight experience, 10 - a very intense negative experience of emotion). The points were divided into three groups: high level of intensity of experience (acute experience) - 7-10 points; average level of intensity of experience (experience is disturbing, although not acute) - 4-6 points; moderate level of intensity of experience (barely perceptible experience) - 1-3 points.

At the formative stage of the study, the client on the session with a psychologistpsychotherapist describes the emotional experiences that concern him. That helps to focus the 
client's attention on this negative emotional experience, which is relevant at the time of the session. If it is difficult for the client to identify the negative emotional experience, the psychotherapist directs the client to evoke images related to the traumatic situation, or to recall the bodily feelings and emotions he experienced in the psycho-traumatic situation.

Psychologist-psychotherapist leads the client, giving him commands to internalize the focus on the emotional experience for 3-15 seconds, and then to exteriorize the focus on the environment (objects that surround at the present time: table, window, floor, switch, laptop, etc.) for 3-15 seconds with the condition of conscious perception of each of the objects. The process repeats until the negative emotional experience subsides.

On average, different clients need from 10 to 30 minutes to process one negative emotional experience with the technique of internalization and exteriorization of the focus of attention. Time of processing depends on the intensity of the negative emotional experience or the traumatic situation for the human psyche. In some cases, the negative emotional experience does not subside in 1 psychotherapy session, although its processing significantly reduces its intensity. Additional sessions with a certain emotional experience were held for such clients. In general, the psychotherapy session ends with a re-diagnosis of the presence or absence of negative emotional experience of the client, with whom the technique of internalization and exteriorization of the focus of attention was carried out. Based on the assessment interview, the client re-evaluates the intensity of the emotional experience.

\section{Discussion results}

Emotions and mental states are infused into the behavior, the assertiveness of the person, the particularity of his social contacts and the interruption of large mental processes. The influence of emotions on the formation of value-semantic and motivational spheres of personality is also important.

Izard K. E. determines the influence of emotions on various systems of the individual, such as: consciousness, perception, cognitive processes, organization of actions. The complex of experiences of a person determines his mental state in general. Also, the dependence of the development of the internal mental structures of man on what emotional states he has is emphasized (Izard, 2000). For example, in a state of anxiety, it is difficult to concentrate or remember, and irritability can affect creativity or the quality of thinking in the present situation.

Most often, the emotional reaction becomes a psychological problem when a person experiences negative emotions not in relation to current circumstances, but as if carrying the "burden" of past experience (Poviakel \& Zaychikova, 2012). Accordingly, person is not able to independently realize its transience and release from its negative impact on current life. Therefore, psychotherapeutic interventions of negative emotional experiences are used in treatment of emotional experiences of tough past situation that person could not live through and integrate.

Another aspect of the analyzed problem may be the modeling by the person of an undesirable future under the influence of past negative emotional experiences that have not been integrated and perceived by the individual as the past. This can be expressed in unreasonable feelings of anxiety about the future or the feeling that "something bad will happen". Also, there may be even periodic "falling" into depressive states, especially when the situation of past negative emotional experience and accompanying experiences is periodically updated (for example, meeting with the person who was the cause of such experiences; the need to repeat or even periodically visit those places where traumatic events took place, etc.). In particular, today such a situation is quite 
relevant for migrants from the East of Ukraine, when they hear about such events from the media or visit relatives (grandparents) who remained in the occupied territories.

We will analyze the results of the study by the method of $A \& D$, which measures chronic and/or habitual mental states of the person, less focusing on current mood states. The application of this technique allowed to assess the general states of anxiety and depression and their dynamics in the process of psychotherapy treatment (see table 1 and table 2).

Table 1

Dynamics of anxiety indicators in the experimental group according to the A\&D method before and after the use of the technique of internalization and exteriorization of the focus of attention (in \%), $\mathrm{n}=\mathbf{2 0}$

\begin{tabular}{|c|c|c|c|c|}
\hline Mental states & Before & After & $\begin{array}{c}\text { Dynamics } \\
\text { indicators }\end{array}$ & $\begin{array}{c}\text { Values of } \\
\text { coefficients }\end{array}$ \\
\hline Positive mental states & 25 & 40 & +15 & $\mathrm{x} \geq 1.28$ \\
\hline Satisfactory mental states & 25 & 35 & +10 & $-1.28 \leq \mathrm{x} \leq 1.28$ \\
\hline Boundary mental states & 15 & 0 & -15 & $\mathrm{x} \leq-5.6$ \\
\hline Anxiety & 35 & 25 & -10 & $-5.6 \leq \mathrm{x} \leq-1.28$ \\
\hline
\end{tabular}

In general, in the process of the ascertaining stage of the study it was found that half of the test subjects (50\%) experienced negative emotional experiences (35\% - anxiety, 15\% - borderline mental states). Another $50 \%$ of test subjects $-25 \%$ respectively, have positive and satisfactory mental states. Negative (anxiety) and borderline mental states can signal the development of GAD (generalized anxiety disorder). One of the features of this disorder is that a person is constantly worried about the future, about possible dangers, diseases, problems and catastrophes that could potentially occur in his life or the lives of his relatives (Borkovec \& Hazlett-Stevens \& Diaz, 1999). Having a GAD, a person can live in the captivity of terrible scenarios of the future, hesitation in making decisions in the present and solving current issues of his life (Marker \& Aylward, 2017).

After the intervention of negative emotional experiences with the technique of internalization and exteriorization of the focus of attention, the percentage of test subjects in positive mental states $(\mathrm{x} \geq 1.28)$ and satisfactory mental states $(-1.28 \leq \mathrm{x} \leq 1.28)$ increased by $15 \%$ and $10 \%$ respectively. Indicators of borderline mental states $(\mathrm{x} \leq-5.6)$ and anxiety indicators $(-5.6 \leq x \leq-1.28)$, on the contrary, decreased by $15 \%$ and $10 \%$ respectively.

For visualization, the results of the study are presented in figure 1 (*exteriorization and internalization of the focus of attention).

Quite often anxiety has a comorbidity with depressive states. The connection between anxiety and depression is due to the fact that constant anxiety exhausts and weakens a person, deprives him of the strength to productively solve current issues. This leads to a closed cycle "depressive thinking - depressive behavior - accumulation of problems - depressive states due to accumulation of problems - depressive thinking” (Beck, J., 2010).

Below in the table 2 presents indicators of various mental states, in particular, depression according to the method of A\&D. 


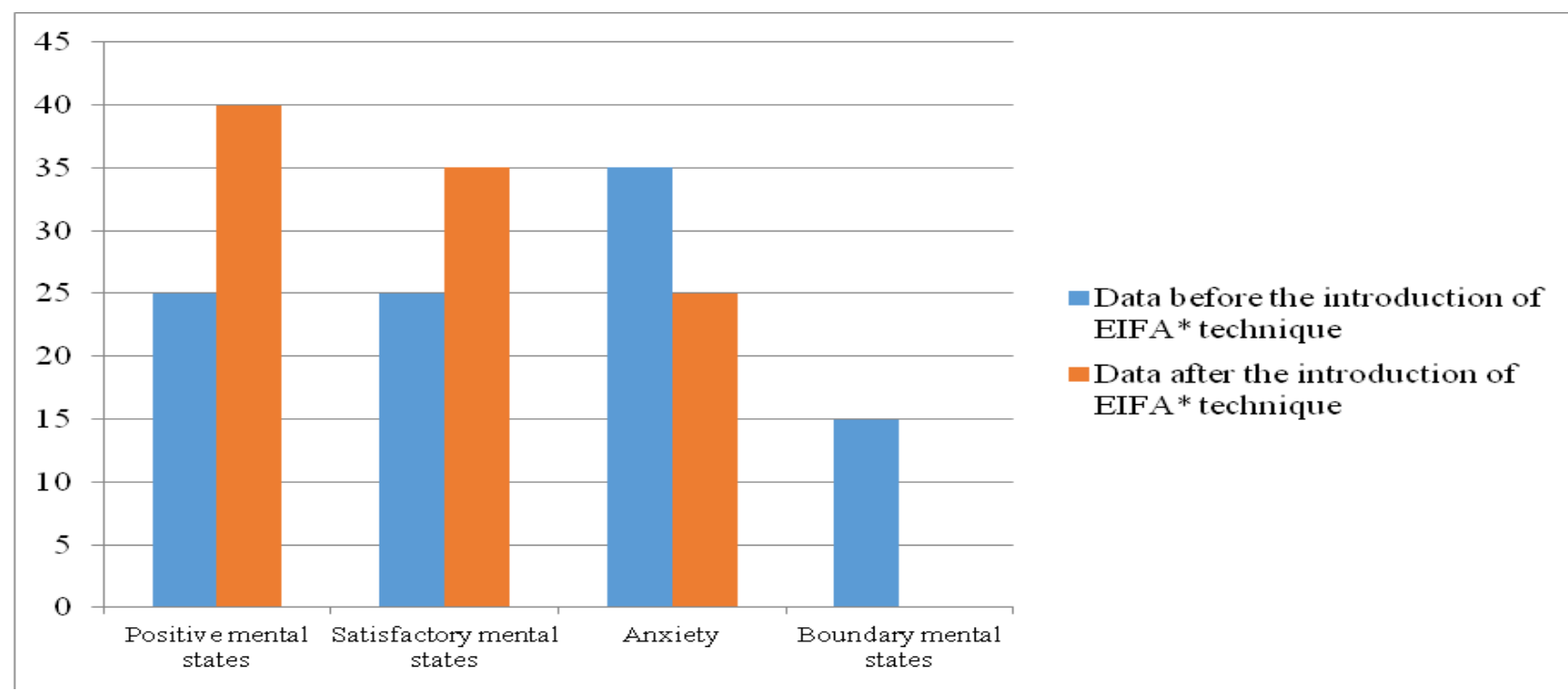

Figure 1. Dynamics of quantitative indicators of mental states of the studied experimental group before and after psychotherapeutic interventions with the technique of exteriorization and internalization of the focus of attention (according to the method of A\&D, anxiety).

Table 2

Dynamics of depression indicators in the experimental group according to the A\&D method before and after the use of the technique of internalization and exteriorization of the focus of attention (in $\%$ ), $n=20$

\begin{tabular}{|c|c|c|c|c|}
\hline Mental states & Before & After & $\begin{array}{c}\text { Dynamics } \\
\text { indicators }\end{array}$ & $\begin{array}{c}\text { Values of } \\
\text { coefficients }\end{array}$ \\
\hline Positive mental states & 20 & 20 & 0 & $\mathrm{x} \geq 1.28$ \\
\hline Satisfactory mental states & 10 & 45 & +35 & $-1.28 \leq \mathrm{x} \leq 1.28$ \\
\hline Boundary mental states & 35 & 10 & $-25 \%$ & $\mathrm{x} \leq-5.6$ \\
\hline Depression & 35 & 25 & -10 & $-5.6 \leq \mathrm{x} \leq-1.28$ \\
\hline
\end{tabular}

At the ascertaining stage, only $30 \%$ of test subjects did not have pronounced negative experiences (20\% positive mental states, $10 \%$ satisfactory mental states). The vast majority of test subjects $(70 \%)$ had negative emotional experiences $(35 \%$ - borderline mental states, 35\% depression).

In addition to depressed mood, depression has a number of other symptoms. Such symptoms include: change in appetite, sleep disturbance, psychomotor arousal or inhibition, decreased energy potential, feelings of inferiority or guilt, impaired concentration, suicidal thoughts and more.

Perceptions, interpretations and recollections of events can be distorted, so people with depression are more likely to interpret any information negatively and to see the future in pessimistic tones (Westbrook, Kennerley \& Kirk, 2014).

After the psychotherapeutic treatment with the technique of internalization and exteriorization of the focus of attention, the percentage of test subjects within satisfactory mental states $(-1.28 \leq \mathrm{x} \leq 1.28)$ increased by $35 \%$. The rate of borderline mental states decreased in $25 \%$ of test subjects $(\mathrm{x} \leq-5.6)$ and the rate of depression decreased in $10 \%$ of test subjects $(-5.6 \leq \mathrm{x} \leq-1.28)$. Thus, in a significant part of test subjects borderline and depressive states have changed to satisfactory mental states. 
For visualization, the results of the study are presented in figure 2. (*exteriorization and internalization of the focus of attention).

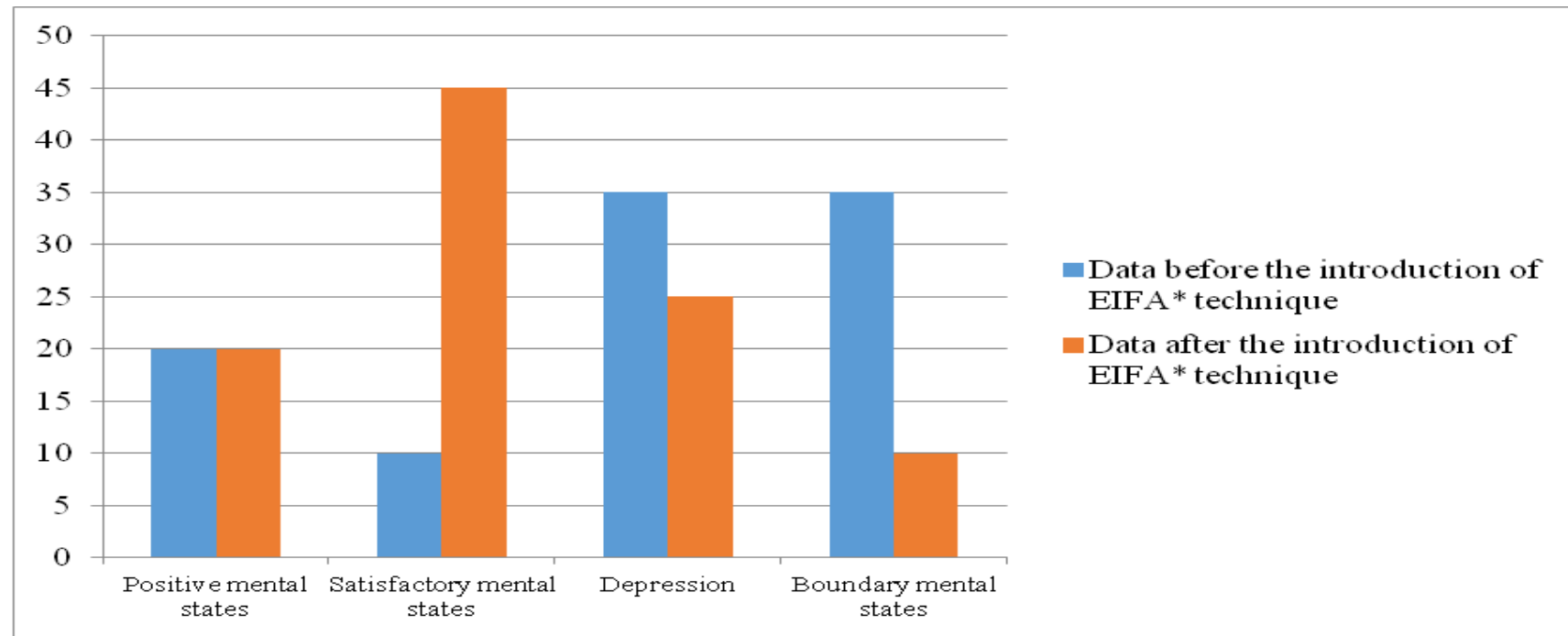

Figure 2. Dynamics of quantitative indicators of mental states of the studied experimental group before and after psychotherapeutic interventions with the technique of exteriorization and internalization of the focus of attention (A\&D method, depression)

Thus, according to the results of the formative stage of the study in the process of psychotherapeutic intervention, not only the indicators of anxiety decreased, but also the indicators of the manifestation of depressive states.

Comparison of the obtained indicators by the method of assessment interview showed that before the use of the technique of internalization and exteriorization of the focus of attention in $75 \%$ of test subjects negative mental states reached a high level of intensity, another $15 \%$ had a medium level of experience and $10 \%$ moderate the level of intensity of experiences.

According to the results of the formative stage of the study, it was found that after the introduction of the technique of internalization and exteriorization of the focus of attention in all participants of psychotherapeutic treatment the emotional state generally improved: in $80 \%$ of test subjects it acquired a moderate level of intensity and in $20 \%$ the average level of intensity. The redistribution of indicators was due to a decrease in the percentage of subjects with a high level of intensity of negative experiences.

Based on the analysis of the results of re-diagnosis by all methods, a conclusion was made about the effectiveness of the proposed technique of internalization and exteriorization of the focus of attention in the psychotherapy treatment of negative emotional experiences of adults.

Thus, as shown by the results of the study, the quantitative indicators of experiencing negative emotional states of the test subjects of the experimental group were significantly reduced or disappeared altogether. Clients, in the process of mastering the technique of internalization and exteriorization of the focus of attention, have learned to cope with such negative mental states or consciously control their course, which ensured more successful adaptive behavior.

\section{Conclusions}

Theoretical analysis of the problem showed that negative emotional experiences from which a person is not freed, can inhibit personal development, form a complex of inferiority, be the cause of increased aggression, depression or anxiety, or develop into neurotic states. In addition, negative experiences have an impact on personal motivation, behavior and characteristics of social 
interaction. Therefore, psychotherapy practice faces the task of freeing clients from both current negative emotional experiences and memories that cause these experiences.

Emotional load and the peculiarity of the psychotherapeutic process requires from the client a conscious effort and focus on the successful solution of a psychological problem, and from a practicing psychologist-psychotherapist requires high qualification, thorough professional skills and a wide arsenal of proper techniques.

To reduce the level of negative personal experiences caused by memories of past traumatic events, we used a modified version of the psychotherapeutic technique of internalization and exteriorization of the focus of attention, based on techniques of trauma-focused therapy, exposurebased techniques in cognitive-behavioral therapy and EMDR.

At the confirmatory stage of the study, it was found that half of the test subjects had anxiety states, depressive states, or borderline mental states associated with specific problems in social, professional, and interpersonal relationships. The psychophysiological condition of the test subjects can be characterized by the following symptoms: anxiety, hypothymia, irritability, insecurity, muscle tension, fatigue, sleep disorders. Also, one of the features of anxiety is a constant worry about the future and the possible dangers that can potentially occur in life; depressive states depressive ruminations and "depressive" behavior.

At the formative stage of the study it was found that as a result of using the technique of internalization and exteriorization of the focus of attention for psychotherapy treatment of negative emotional experiences in more than half of the experimental group improved general emotional state, decreased anxiety and depressed mood, restored self-confidence, which ensured successful adaptive behavior.

Prospects for further research are to test the effectiveness of the proposed technique of internalization and exteriorization of the focus in the psychotherapy of negative experiences of adulthood in a wider sample of subjects.

\section{Literature}

1. Анцупов, А.Я., \& Баклановский, С.В. (2006). Конфликтология в схемах и комментариях. Санкт-Петербург : Питер.

2. Большой психологический словарь (2003). Под ред. Мещерякова, Б.Г., \& Зинченко, В.П. Москва : Прайм-еврознак.

3. Бондырева, С.К. (2007). Переживание (психология, социология, семантика): учеб. пособие. Москва : Издательство Московского психолого-социального института.

4. Брієр, Д., \& Скотт, К. (2015). Основи травмофокусованої терапії. Львів : Свічадо.

5. Веккер, Л.М. (1998). Психика и реальность: единая теория психических прочессов. Москва : Смысл. Режим доступу: https://gtmarket.ru/laboratory/basis/6487/6508\#contents

6. Вестбрук, Д., \& Кеннерлі, Г. (2014). Вступ у когнітивно-поведінкову терапію. Львів : Свічадо.

7. Гофман, А. (2017). EMDR Терапія наслідків психотравми, практичний посібник. Львів : Свічадо.

8. Изард, К.Э. (2000). Психология эмоичй. Санкт-Петербург : Питер.

9. Карелин, А. (2007). Большая энщиклопедия психологических тестов. Москва : Эксмо, 3536.

10. Колесніченко, Л.А. (2019). Особливості надання психологічної допомоги особам 3 психосоматичними розладами. Соціальна психологія сьогодні: здобутки і перспективи: матеріали доповідей учасників II Всеукраӥнського Конгресу із сочіальної психології. Київ. 
Інститут соціальної та політичної психології НАПН України, С. 165-167. Режим доступу: http://ispp.org.ua/wp-content/uploads/2019/11/Theses-UCSP2019.pdf

11. Лёйнер, Х. (1996). Кататимное переживание образов. Основная ступень: Введение 8 психотерапию с использованием техники сновидений наяву. Москва : Эйдос.

12. Малкина-Пых, И.Г. (2005). Психологическая помощзь в кризисных ситуащиях. Москва : Эксмо. 960.

13. Маркер, К., \& Ейлворд, Е. (2017). Генералізований тривожний розлад. Львів : Свічадо.

14. Перлз, Ф., Хефферлин, Р., \& Гудмэн, П. (2004). Практика гештпльттерапиии. Перевод Папуша, М.П. Москва : Институт Общегуманитарных Исследований.

15. Пов'якель, Н., \& Зайчикова, Т. (2012). Психологічні передумови виникнення стресових реакцій особистості. Науковий часопис НПУ імені М. П. Драгоманова. Серія 12: Психологічні науки. 37(61), 189-195. Режим доступу: http://enpuir.npu.edu.ua/bitstream/12 3456789/26243/1/Poviakel_Zaichykova.pdf

16. Улько, Н.М. (2020). Чинники виникнення психотравми в дорослому віці. Наукові записки Національного університету «Острозька академія». Серія «Психологія»: науковий журнал. Острог : Вид-во НаУОА. № 10, 91-95.

17. Beck, J. (2010). Cognitive Therapy. Retrieved from https://doi.org/10.1002/9780470479216.corpsy019

18. Beck, J. (2005). Cognitive therapy for Challenging problems. NY : Guilford press.

19. Borkovec, T., Hazlett-Stevens, H., \& Diaz, M. (1999). The role of positive beliefs about worry in generalized anxiety disorder and its treatment. Retrieved from https://doi.org/10.1002/(SICI)1099-0879(199905)6:2\%3C126::AID-CPP193\%3E3.0.CO;2-M

20. Briere, J. (2013) Mindfulness, insight and trauma therapy. In Germer, C., Siegel, R., Fulton, P. Mindfulness and psychotherapy (2end edition). NY : Guilford.

21. Clarke, D., \& Beck, A. (2009). Cognitive therapy of anxiety disorders. NY : Guilford press.

22. Ellis, A., \& Dryden, W. (1997). The practice of Rational Emotive behavior Therapy. Second edition. NY : Springer Publishing Company.

23. Freud, S. (2012). The Basic Writings of Sigmund Freud. Random House Publishing Group, 922.

24. Hase, M., Balmaceda, U.M., Hase, A., Lehnung, M., Tumani, V., Huchzermeier, C., \& Hofmann, A. (2015). Eye movement desensitization and reprocessing (EMDR) therapy in the treatment of depression: a matched pairs study in an inpatient setting. Retrieved from: https://doi.org/10.1002/brb3.342https://doi.org/10.1002/brb3.342

25. Marcher, L., \& Fich, S. (2007). Body Encyclopedia: A Guide to the Psychological Functions of the Muscular System. North Atlantic Books.

26. Myers, K., \& Davis, M. (2007). Mechanisms of fear extinction. Molecular Psychiatry, 12, 120150.

27. Segal, Z., Williams, J., \& Teasdale, J. (2001). Mindfulness-based Cognitive Therapy for depression. NY : Guilford press.

28. Shapiro, F. (2017). Eye Movement Desensitization and Reprocessing (EMDR) Therapy, Third Edition: Basic Principles, Protocols, and Procedures. Guilford Publications. Retrieved from https://www.guilford.com/books/Eye-Movement-Desensitization-and-Reprocessing-EMDRTherapy/Francine-Shapiro/9781462532766

29. Stavytska, S.O., Stavytsky, G.A., \& Ulko, N.M. (2019). Overcoming psyhoemotional traumatization personality in terms unstable present day. Украӥнський психологічний журнал: збірник наукових пращь. Київ, КНУ імені Тараса Шевченка, 1(11), 204-213. 


\section{References}

1. Ancupov, A.Ja., \& Baklanovskij, S.V. (2006). Konfliktologija v shemah i kommentarijah [Conflictology in diagrams and comments]. St. Petersburg : Peter [in Russian].

2. Bol'shoj psihologicheskij slovar' [Big psychological dictionary] (2003). Edited by Meshherjakova, B.G., \& Zinchenko, V.P. Moscow : Prajm-evroznak [in Russian].

3. Bondyreva, S.K. (2007). Perezhivanie (psihologija, sociologija, semantika): ucheb. posobie [Experiencing (psychology, sociology, semantics): textbook]. Moscow : Publishing house of the Moscow Psychological and Social Institute [in Russian].

4. Briere, J., \& Scott, C. (2015). Osnovy travmofokusovanoi terapii [Fundamentals of traumafocused therapy]. Lviv: Svichado [in Ukrainian].

5. Vekker, L.M. (1998). Psihika i real'nost': edinaja teorija psihicheskih processov [Psyche and reality: a unified theory of mental processes]. Moscow : Meaning [in Russian]. Retrieved from https://gtmarket.ru/laboratory/basis/6487/6508\#contents

6. Westbrook, D., \& Kennerley, H. (2014). Vstup u kohnityvno-povedinkovu terapiiu [An introduction cognitive-behavioral therapy]. Lviv: Svichado [in Ukrainian].

7. Hofmann, A. (2017). EMDR Terapiia naslidkiv psykhotravmy, praktychnyi posibnyk [Therapy of the consequences of psychotrauma, a practical guide]. Lviv : Svichado [in Ukrainian].

8. Izard, K.Je. (2000). Psihologija jemocij [Psychology of emotions]. St. Petersburg : Peter [in Russian].

9. Karelin, A. (2007). Bol'shaja jenciklopedija psihologicheskih testov [Great encyclopedia of psychological tests]. - Moscow : Eksmo, 35-36 [in Russian].

10. Kolesnichenko, L.A. (2019). Osoblyvosti nadannia psykholohichnoi dopomohy osobam z psykhosomatychnymy rozladamy [Special features of providing psychological assistance to individuals with psychosomatic disorders]. Social Psychology of the Year: Prospects and Prospects: Materials of the Participants of the II All-Ukrainian Congress on Social Psychology. Kiev. Institute of Social and Political Psychology of the National Academy of Sciences of Ukraine, P.165-167 [in Ukrainian]. Retrieved from: http://ispp.org.ua/wpcontent/uploads/2019/11/Theses-UCSP2019.pdf

11. Leuner, H. (1996). Katatimnoe perezhivanie obrazov. Osnovnaja stupen': Vvedenie v psihoterapiju s ispol'zovaniem tehniki snovidenij najavu [Catatimic experience of images. Main step: Introduction to psychotherapy using the technique of waking dreams]. Seminar: per. with him. Moscow : Eidos [in Russian].

12. Malkina-Pyh, I.G. (2005). Psihologicheskaja pomoshh'v krizisnyh situacijah [Psychological assistance in crisis situations]. Moscow : Eksmo, 960 [in Russian].

13. Marker, C., \& Aylward, A. (2017). Heneralizovanyi tryvozhnyi rozlad [Generalization tricky breakdown]. Lviv : Svichado [in Ukrainian].

14. Perls, F., Heflerline, R., \& Goodman, P. (2004). Praktika geshtpl'tterapiii [Practice gesture therapy]. Translated by Papus, M.P. Moscow: Institute of General Humanitarian Research [in Russian].

15. Poviakel, N., \& Zaichykova, T. (2012). Psykholohichni peredumovy vynyknennia stresovykh reaktsii osobystosti [Psychological reconsideration and determination of stress reactions of specialness]. Naukovy`j chasopy`s NPU imeni M. P. Dragomanova. Seriya 12: Psy`xologichni 
nauky`,37(61), 189-195. Retrieved from http://enpuir.npu.edu.ua/bitstream/123456789/26243 11/Poviakel_Zaichykova.pdf [in Ukrainian].

16. Ulko, N.M. (2020). Chynnyky vynyknennia psykhotravmy v doroslomu vitsi [Officials diagnosed with psycho-traumas in an elderly vice]. Scientific notes of the National University "Ostrozka Academy". Series "Psychology": science journal. Ostrog : View of the NaUAA. No. 10. 91-95 [in Ukrainian].

17. Beck, J. (2010). Cognitive Therapy. Retrieved from https://doi.org/10.1002/9780470479216. corpsy019

18. Beck, J. (2005). Cognitive therapy for Challenging problems. NY : Guilford press.

19. Borkovec, T., Hazlett-Stevens, H., \& Diaz, M. (1999). The role of positive beliefs about worry in generalized anxiety disorder and its treatment. Retrieved from https://doi.org/10.1002/(SICI)1099-0879(199905)6:2\%3C126::AID-CPP193\%3E3.0.CO;2-M

20. Briere, J. (2013) Mindfulness, insight and trauma therapy. In Germer, C., Siegel, R., Fulton, P. Mindfulness and psychotherapy (2end edition). NY : Guilford.

21. Clarke, D., \& Beck, A. (2009). Cognitive therapy of anxiety disorders. NY: Guilford press.

22. Ellis, A., \& Dryden, W. (1997). The practice of Rational Emotive behavior Therapy. Second edition. NY : Springer Publishing Company.

23. Freud, S. (2012). The Basic Writings of Sigmund Freud. Random House Publishing Group, 922 [in English].

24. Hase, M., Balmaceda, U.M., Hase, A., Lehnung, M., Tumani, V., Huchzermeier, C., \& Hofmann, A. (2015). Eye movement desensitization and reprocessing (EMDR) therapy in the treatment of depression: a matched pairs study in an inpatient setting. Retrieved from https://doi.org/10.1002/brb3.342https://doi.org/10.1002/brb3.342

25. Marcher, L., \& Fich, S. (2007). Body Encyclopedia: A Guide to the Psychological Functions of the Muscular System. North Atlantic Books.

26. Myers, K., \& Davis, M. (2007) Mechanisms of fear extinction. Molecular Psychiatry, 12, 120150.

27. Segal, Z., Williams, J., \& Teasdale, J. (2001). Mindfulness-based Cognitive Therapy for depression. NY : Guilford press.

28. Shapiro, F. (2017). Eye Movement Desensitization and Reprocessing (EMDR) Therapy, Third Edition: Basic Principles, Protocols, and Procedures. Guilford Publications. Retrieved from: https://www.guilford.com/books/Eye-Movement-Desensitization-and-Reprocessing-EMDRTherapy/Francine-Shapiro/9781462532766

29. Stavytska, S.O., Stavytsky, G.A., \& Ulko, N.M. (2019). Overcoming psyhoemotional traumatization personality in terms unstable present day. Ukrainskyi psykholohichnyi zhurnal: zbirnyk naukovykh prats. Kyiv : Taras Shevchenko National University. 1(11), 204-213 [in English]. 


\title{
ПСИХОТЕРАПІЯ НЕГАТИВНИХ ПЕРЕЖИВАНЬ ОСОБИСТОСТІ ДОРОСЛОГО ВІКУ ТЕХНІКОЮ ІНТЕРІОРИЗАЦІЇ Й ЕКСТЕРІОРИЗАЦІЇ ФОКУСУ УВАГИ Дар'я Бессонова
}

аспірантка кафедри загальної і соціальної психології та психотерапії

Національний педагогічний університет імені М. П.Драгоманова

01601, Україна, м. Київ, вул. Пирогова, 9

bessonova.dariya@gmail.com, https://orcid.org/0000-0001-6722-7662

\section{Світлана Ставицька}

доктор психологічних наук, професор, завідувачка кафедри загальної і соціальної психології та психотерапії

Національний педагогічний університет імені М. П.Драгоманова

01601, Україна, м. Київ, вул. Пирогова, 9

stavics@ukr.net, https://orcid.org/0000-0003-0800-0876

\begin{abstract}
Анотація
Статтю присвячено аналізу особливостей використання техніки інтеріоризації й екстеріоризації фокусу уваги в психотерапії негативних переживань особистості дорослого віку. Негативні переживання відносяться до психічних станів особистості, що впливають на iï самооцінку, асертивність та особливості перебігу більшості психічних процесів. Негативні переживання, від яких людина не звільнилась, можуть гальмувати іiі особистісний розвиток, сформувати комплекс неповноцінності, бути причиною підвищеної агресивності або тривожності, перерости в невротичні стани. Метою дослідження є теоретичне обгрунтування та емпіричне дослідження ефективності застосування техніки інтеріоризації й екстеріоризації фокусу уваги в психотерапії негативних переживань особистості доросло віку. Психотерапія негативних переживань - це важкий і малоприємний процес для клієнта, який потребує від нього усвідомленої зорієнтованості на подолання таких переживань, а також високої кваліфікації i грунтовних професійних навичок від практикуючого психологапсихотерапевта. У поданій роботі в якості психотерапевтичної інтервенції випробовується модифікована техніка інтеріоризації й екстеріоризації фокусу уваги, яка базується на техніках травма-фокусованої терапії, експозиції негативних переживань в когнітивноповедінковій терапії та EMDR (Eуe movement desensitization and reprocessing десенсибілізація та репроцесуалізація за допомогою руху очима). Запропонована техніка інтеріоризації й екстеріоризації фокусу уваги в психотерапії негативних переживань особистості заснована на почерговому фокусуванні на негативному переживанні (інтеріоризація уваги) та на актуальному зовнішньому середовищі (екстеріоризація уваги) в однакових проміжках часу. Важливим тут $\epsilon$ (у процесі психотерапії) ритміка обробки переживань та свідомий контроль за їх перебігом. За результатами проведеного дослідження виявлено, що впровадження техніки інтеріоризації й екстеріоризації фокусу уваги покращило емоційний стан досліджуваних: підвищилась впевненість в особистісних ресурсах, знизився страх майбутнього та рівень занепокоєння, також прослідковується позитивна динаміка зміни настрою. Досліджувана техніка $є$ досить вузько спрямованою щодо опрацювання негативних переживання, проте було виявлено, що у процесі психотерапевтичної роботи, також, має місце позитивний вплив на загальний емоційний стан особистості.
\end{abstract}

Ключові слова: негативні переживання, психотерапія негативних переживань, техніка інтеріоризації й екстеріоризації фокусу уваги, когнітивно-поведінкова терапія. 